\title{
Research on internal control audit, internal control deficiency and
}

\author{
audit fees \\ Ting Pan*, Yu Song \\ School of Economics and Management, Nanjing University of Science and Technology,China \\ *Corresponding author: Ting Pan, postgraduate, TP126YX@126.com
}

\begin{abstract}
With the development of the internal control system, the internal control audit has received more attention.This paper takes the A-share listed companies in Shanghai and Shenzhen as a sample, to study the effect of the disclosure of internal control audit report, the opinion of internal control audit and the repair of internal control deficiencies on audit fees. This paper draws the following conclusions: Companies that perform internal control audits pay higher audit fees; When the company's internal control report is issued a standard unqualified opinion, the audit fees will be reduced; Repair of the internal control deficiencies will result in lower audit fees for the following year.
\end{abstract}

Key words: internal control audit; audit fees; internal control deficiency

\section{Introduction}

\subsection{Background}

At the beginning of the 21st century, a series of financial fraud cases had aroused the concern of the community on the internal control system. In 2002, the US Congress passed the Sarbanes-Oxley Act, where the Section 302 and Section 404 require company's managers to issue a self-evaluation report on the internal control system, and then were audited by an accounting firm. After that, the US internal control audit system began to develop gradually.China's internal control audit system started later than the United States. In 2008, the "Basic Norms of Internal Control" provides that listed companies should disclose the report on the effectiveness of internal control, and can be audited by an accounting firm. In 2010, the "Guidelines for Corporate Internal Control" stipulates that since 2012, all of the listed companies in Shanghai and Shenzhen must gradually implement internal control audits.With the development of internal control system, the internal control audit has also received more attention.

This paper attempts to study the influence of internal control audit report's disclosure, internal control audit opinion and the repair of internal control deficiencies on audit fees, in order to enrich the research in this field and provide reference for the implementation and improvement of internal control system in China. 


\subsection{Literature review and hypothesis}

After the implementation of Section 404, many scholars study the impact on the cost of the company. Iliev ${ }^{1}$ (2010)find that Section 404 lead to a significant increase in audit fees for the company. Doogar et al. ${ }^{2}$ (2010) conclude that compared with AS2, AS5 can reduce the audit fees of low-risk company and improve the audit fees of high-risk company. Alexander et al. ${ }^{3}$ (2013) find in the early implementation of Section 404, the cost is generally higher than the proceeds, but with the correction of internal control deficiencies, the company will achieve more significant gains The implementation of the internal control audit means that auditors need to take on more legal responsibility and face higher audit risk, which will greatly increase the auditor's effort and the audit fees. So, we can assume that:

H1: The implementation of internal control audit will increase company's audit fees.

Risk-oriented audit requires auditors to know the company's internal control system to identify the risks. Krishnan et al. $^{4}$ (2008) find that audit fees are positively correlated with factors such as the internal control deficiencies. Hogan and Wilkins ${ }^{5}$ (2008) confirm that audit fees are significantly positively correlated with the accounting firms. When the company's internal control audit report is issued non-standard opinion, it means that the company's internal control is flawed, the auditors cannot trust the its internal control system, which will increase the effort and then improve audit fees. So, we can assume that:

H2: Higher quality of the company's internal control will lead to lower audit fees

After company discloses its internal control deficiencies, the repair of the deficiencies will also affect audit fees. Santanu Mitra ${ }^{6}$ (2009) find that audit fees are negatively correlated with the repair of internal control deficiencies. Hoag and Hollingsworth ${ }^{7}$ (2011) find that the company's major internal control deficiencies will reduce audit fees. Krishnan and Song ${ }^{8}$ (2011) find that the companies with repaired internal control deficiencies will have a significant change in audit fees for the following year. If the deficiencies are not repaired, the internal control quality is low and will not be improved in short term. In order to reduce the audit risk, auditors need to increase the audit effort and audit resources, thereby increasing audit fees. So we can assume that:

H3: Repair of internal control deficiencies will reduce the audit fees in future

\section{Experimental}

\subsection{Sample}

This paper takes the A-share listed companies in Shanghai and Shenzhen from 2012 to 2016 as a sample, excluding samples of financial and insurance industry, samples of ST and ST ${ }^{*}$ and eliminating missing data, and finally obtains 12152 sample data. In order to verify the hypothesis H2, this paper further screens companies that published internal audit reports in the last five years and obtains 8845 sample data. In order to verify the hypothesis H3, this paper further screens the company that disclosed the deficiencies of the internal control in the last five years, and obtains 2924 sample data. All data is obtained from the CSMAR database 
and processed by Stata 14.0 .

\subsection{Model specifications and variable definitions}

This paper estimates Model (1), Model (2) and Model (3) to verify H1, H2 and H3 respectively:

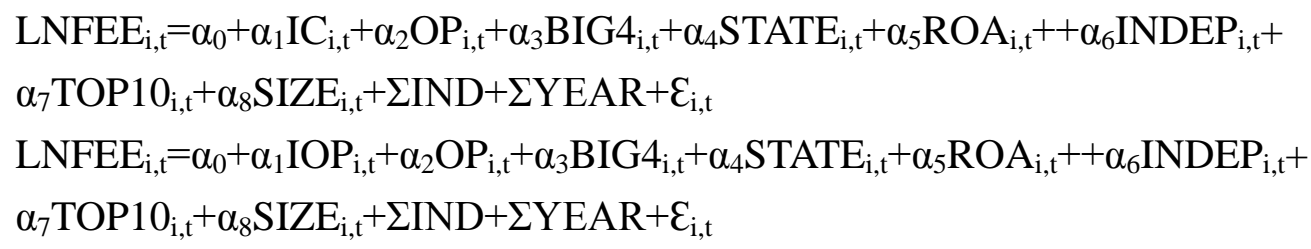

$\mathrm{LNFEE}_{\mathrm{i}, \mathrm{t}}=\alpha_{0}+\alpha_{1} \mathrm{REM}_{\mathrm{i}, \mathrm{t}}+\alpha_{2} \mathrm{OP}_{\mathrm{i}, \mathrm{t}}+\alpha_{3} \mathrm{BIG}_{\mathrm{i}, \mathrm{t}}+\alpha_{4} \mathrm{STATE}_{\mathrm{i}, \mathrm{t}}+\alpha_{5} \mathrm{ROA}_{\mathrm{i}, \mathrm{t}}++\alpha_{6} \mathrm{INDEP}_{\mathrm{i}, \mathrm{t}}+$ $\alpha_{7} \mathrm{TOP} 10_{\mathrm{i}, \mathrm{t}}+\alpha_{8} \mathrm{SIZE}_{\mathrm{i}, \mathrm{t}}+\Sigma \mathrm{IND}+\Sigma \mathrm{YEAR}+\varepsilon_{\mathrm{i}, \mathrm{t}}$

The dependent variable is LNFEE, since most listed companies do not disclose financial reports, audit fees and internal control audit fees respectively in their annual reports, this paper takes the natural logarithm of audit fees as a measure.

IC (H1),is an dummy variable that equals to one if the company discloses an internal control audit report; zero otherwise. IOP(H2),is an dummy variable that equals to one if the internal audit report is issued with the standard unqualified opinion, which means the internal control quality of the company is high; zero otherwise. If the internal control deficiencies disclosed by the company has been repaired or partially repaired, REM (H3) equal to one, zero otherwise.

The control variables include OP(equal to one if the company's financial report is issued a standard unqualified opinion, zero otherwise),BIG4(equal to one when the auditor comes from Big4 firms),STATE(equal to one if the company is state-owned holding),ROA(it is measured as net profit scaled by total asset),INDEP(it is measured as number of independent directors scaled by the total number of directors), TOP10(percentage of shares held by the top10 institutional owners) and SIZE(the natural logarithm of total assets).All the models will be tested by OLS regression.

\section{Results and Discussion}

\subsection{Summary statistics}

Table 1 presents the summary statistics for the main variables.

The minimum value of LNFEE is 12.54 , the maximum value is 16.30 , which means there is a big difference between the company's audit fees. The average of IC is 0.73 , indicating that most companies in the sample have disclosed the internal control report. The average of IOP is 0.97 , indicating that most of the internal control reports are issued with standard unqualified comments. REM has a mean of 0.42 and a median of zero, indicating that less than half of the companies repair or partially repair the disclosed internal control deficiencies. The average of BIG4 is only 0.05 , meaning that only $5 \%$ of the companies in the sample hire Big4 firms. The average of TOP10 is 59\%, indicating that the company's equity concentration is relatively high. 
Table 1 - Descriptive statistics on main variables

\begin{tabular}{ccccccc}
\hline Variable & $\mathrm{N}$ & Mean & Std Dev & Median & Min & Max \\
\hline LNFEE & 12,152 & 13.69 & 0.68 & 13.59 & 12.54 & 16.30 \\
IC & 12,152 & 0.73 & 0.44 & 1 & 0 & 1 \\
IOP & 8,845 & 0.97 & 0.18 & 1 & 0 & 1 \\
REM & 2,924 & 0.42 & 0.49 & 0 & 0 & 1 \\
OP & 12,152 & 0.98 & 0.16 & 1 & 0 & 1 \\
BIG4 & 12,152 & 0.05 & 0.23 & 0 & 0 & 1 \\
STATE & 12,152 & 0.35 & 0.48 & 0 & 0 & 1 \\
ROA & 12,152 & 0.04 & 0.05 & 0.04 & -0.14 & 0.19 \\
INDEP & 12,152 & 0.37 & 0.05 & 0.33 & 0.33 & 0.57 \\
TOP10 & 12,152 & 0.59 & 0.15 & 0.60 & 0.23 & 0.90 \\
SIZE & 12,152 & 22.04 & 1.27 & 21.87 & 19.57 & 25.93 \\
\hline
\end{tabular}

\subsection{OLS regression}

All hypothesis models are significant, having $\mathrm{R}^{2}$ of over 0.65 .Table 2 presents results of hypothesis tests. The results of Model(1)are shown in column(1) in Table 2.The coefficient of IC is statistically significant at the $1 \%$ level $(\mathrm{t}=9.42)$. BIG4 $(\mathrm{t}=37.97)$ and SIZE $(\mathrm{t}=92.95)$ are significantly positively related to audit fees, are statistically significant at the $1 \%$ level, meaning companies that hire Big 4 firms have higher audit fees, and the larger the company is, the higher the audit fees. OP ( $\mathrm{t}=-7.78)$ and STATE $(\mathrm{t}=-4.59)$ are significantly negatively correlated with audit fees at the $1 \%$ level. If the financial reports are issued by non-standard unqualified, the company have to pay higher audit fees. And compared with state-owned companies, non-state-owned companies’ audit fees are higher.

This paper examines the impact of internal control quality on audit fees. The results are shown in column(2) in Table 2.H2 is confirmed, as the coefficient of IOP is statistically negatively significant at the $5 \%$ level $(\mathrm{t}=-2.33)$. When the company's internal control report is issued with standard unqualified opinion, its audit fees will be reduced.BIG4 and SIZE are significantly positively correlated with audit fees, and OP and STATE are significantly negatively correlated with audit fees, which is consistent with the regression results of Model(1).ROA(t=-2.92) is significantly negatively correlated with audit fees, that is, the improvement of the company's operating conditions will reduce its audit fees.

According to Model (3), this paper examines whether the repair of internal control deficiencies will reduce audit fees for the next year. The results are shown in column(3) in Table 2.REM(t=-3.02) is negatively correlated with the audit fees at $1 \%$ level, which means the repair of the internal control defect will reduce the audit fees and H3 is confirmed. The correlations of control variables are basically the same as before. 


\subsection{Robustness analysis}

This paper performs the robustness test by replacing the audit fees. New LNFEE takes audit fee rate (it is measured as audit fees scaled by total asset) as a measure. The new OLS regression results are shown in column(4)-(6) in Table 2.All hypothesis models are significant, having $\mathrm{R}^{2}$ of over 0.74 .The regression results are basically consistent with the results in Table 2. IC and LNFEE are positively correlated at the 1\% level; IOP and LNFEE are negatively correlated at the $1 \%$ level, and the significance was better. REM is negatively correlated with LNFEE at the $1 \%$ level.

Overall, the audit results are not affected by audit fee rate instead of audit fees.

Table 2 - OLS Regression

\begin{tabular}{|c|c|c|c|c|c|c|}
\hline Variable & (1) & (2) & (3) & (4) & (5) & (6) \\
\hline Intercept & $\begin{array}{c}5.495^{* * *} \\
(62.62)\end{array}$ & $\begin{array}{c}5.362 * * * \\
(51.12)\end{array}$ & $\begin{array}{c}5.647^{* * *} \\
(30.84)\end{array}$ & $\begin{array}{c}5.926 * * * \\
(58.86)\end{array}$ & $\begin{array}{c}5.815^{* * *} \\
(48.73)\end{array}$ & $\begin{array}{c}5.937 * * * \\
(31.00)\end{array}$ \\
\hline IC & $\begin{array}{c}0.082^{* * *} \\
(9.42)\end{array}$ & & & $\begin{array}{c}0.082^{* * *} \\
(8.20)\end{array}$ & & \\
\hline IOP & & $\begin{array}{c}-0.063^{* *} \\
(-2.33)\end{array}$ & & & $\begin{array}{c}-0.113^{* * *} \\
(-3.65)\end{array}$ & \\
\hline REM & & & $\begin{array}{c}-0.052^{* * *} \\
(-3.02)\end{array}$ & & & $\begin{array}{c}-0.052 * * * \\
(-2.90)\end{array}$ \\
\hline OP & $\begin{array}{c}-0.185^{* * *} \\
(-7.78)\end{array}$ & $\begin{array}{c}-0.178^{* * *} \\
(-5.75)\end{array}$ & $\begin{array}{c}-0.111^{* * *} \\
(-2.65)\end{array}$ & $\begin{array}{c}-0.352 * * * \\
(-12.92)\end{array}$ & $\begin{array}{c}-0.337^{* * *} \\
(-9.55)\end{array}$ & $\begin{array}{c}-0.153^{* * *} \\
(-3.50)\end{array}$ \\
\hline BIG4 & $\begin{array}{c}0.657 * * * \\
(37.97)\end{array}$ & $\begin{array}{c}0.679 * * * \\
(34.93)\end{array}$ & $\begin{array}{c}0.655^{* * *} \\
(19.50)\end{array}$ & $\begin{array}{c}0.662 * * * \\
(33.34)\end{array}$ & $\begin{array}{c}0.674 * * * \\
(30.46)\end{array}$ & $\begin{array}{c}0.646^{* * *} \\
(18.39)\end{array}$ \\
\hline STATE & $\begin{array}{c}-0.041^{* * *} \\
(-4.59)\end{array}$ & $\begin{array}{c}-0.038^{* * *} \\
(-3.72)\end{array}$ & $\begin{array}{c}-0.049 * * * \\
(-2.70)\end{array}$ & $\begin{array}{c}-0.046^{* * *} \\
(-4.53)\end{array}$ & $\begin{array}{c}-0.041^{* * *} \\
(-3.54)\end{array}$ & $\begin{array}{c}-0.049 * * \\
(-2.54)\end{array}$ \\
\hline ROA & $\begin{array}{c}-0.239 * * * \\
(-2.81)\end{array}$ & $\begin{array}{c}-0.308^{* * *} \\
(-2.92)\end{array}$ & $\begin{array}{c}-0.569 * * * \\
(-2.97)\end{array}$ & $\begin{array}{l}-0.159 \\
(-1.63)\end{array}$ & $\begin{array}{c}-0.199 * \\
(-1.66)\end{array}$ & $\begin{array}{c}-0.393^{*} \\
(-1.96)\end{array}$ \\
\hline INDEP & $\begin{array}{c}0.166^{* *} \\
(2.42)\end{array}$ & $\begin{array}{c}0.177^{* *} \\
(2.12)\end{array}$ & $\begin{array}{l}0.216 \\
(1.36)\end{array}$ & $\begin{array}{c}0.194^{* *} \\
(2.46)\end{array}$ & $\begin{array}{c}0.233^{* *} \\
(2.44)\end{array}$ & $\begin{array}{l}0.193 \\
(1.16)\end{array}$ \\
\hline TOP10 & $\begin{array}{l}0.042 * \\
(1.66)\end{array}$ & $\begin{array}{l}0.017 \\
(0.54)\end{array}$ & $\begin{array}{l}0.090 \\
(1.59)\end{array}$ & $\begin{array}{l}0.033 \\
(1.14)\end{array}$ & $\begin{array}{l}0.010 \\
(0.28)\end{array}$ & $\begin{array}{l}0.079 \\
(1.33)\end{array}$ \\
\hline SIZE & $\begin{array}{c}0.370^{* * *} \\
(92.95)\end{array}$ & $\begin{array}{c}0.384 * * * \\
(82.36)\end{array}$ & $\begin{array}{c}0.372^{* * *} \\
(45.08)\end{array}$ & $\begin{array}{c}-0.645^{* * *} \\
(-141.11)\end{array}$ & $\begin{array}{l}-0.630 * * * \\
(-118.80)\end{array}$ & $\begin{array}{c}-0.640 * * * \\
(-74.18)\end{array}$ \\
\hline IND & \multicolumn{6}{|c|}{ Control } \\
\hline YEAR & \multicolumn{6}{|c|}{ Control } \\
\hline $\mathrm{N}$ & 12,152 & 8,845 & 2,924 & 12,152 & 8,845 & 2,924 \\
\hline Adj $R^{2}$ & 0.663 & 0.677 & 0.659 & 0.742 & 0.741 & 0.765 \\
\hline
\end{tabular}

Notes: ${ }^{* * *},{ }^{* * *}$ respectively statistically significant at the $10 \%, 5 \%, 1 \%$ level. 


\section{Conclusions}

This paper studies the impact of internal control audit and internal control deficiencies on audit fees by using the A-share listed companies in Shanghai and Shenzhen from 2012 to 2016 as the sample.This paper draws the following conclusions: The company's internal control audit will increase the audit fees, since the implementation of the internal control audit will increase the auditors' efforts. Improvements in the quality of the company's internal controls can lead to lower audit fees. When the company's internal control report is issued with a standard unqualified opinion, it means that the quality of internal control is high, the auditor will trust the company's internal control, which may reduce the work of substantive procedures and audit resources, resulting in lower audit fees. Repair of internal control deficiencies can lead to lower audit fees for the following year. The improvement of internal control deficiencies indicates that the internal control environment has improved, which will enhance the auditor's trust in the company, to a certain extent reduce the audit risk and the annual audit fees. This paper provides new empirical evidence for the study of the relationship between internal control audit and audit fees, and provides data support for the implementation and improvement of the internal control system in China.

\section{References}

1. Iliev P.The Effect of SOX Section 404:Costs,Earnings Quality,and Stock Prices[J]. The Journal of Finance.65(2010)1163-1196.

2. Doogar R,Sivadasan P,Solomon I.The Regulation of Public Company Auditing: Evidence from the Transition to AS5[J].Journal of Accounting Research. 48(2010)795-814.

3. Alexander $C$ R,Bauguess $S$ W,Bernile G.Economic effects of SOX Section 404 compliance: A corporate insider perspective[J].Journal of Accounting\& Economics.56(2013) 267-290.

4. Krishnan J, Rama D, Zhang Y. Costs to Comply with SOX Section 404[J]. Auditing A Journal of Practice \& Theory.27(2008)169-186.

5. Hogan C E,Wilkins M S.Evidence on the Audit Risk Model:Do Auditors Increase Audit Fees in the Presence of Internal Control Deficiencies?[J]. Contemporary Accounting Research.25(2008)219-242.

6. Santanu Mitra,Mahmud Hossain.Marks B R.Corporate ownership characteristics and timeliness of remediation of internal control weaknesses[J]. Managerial Auditing Journal.27(2012)846-877.

7. Hoag $M L$, Hollingsworth $C W$. An Intertemporal Analysis of Audit Fees and Section 404 Material Weaknesses[J]. Auditing A Journal of Practice \& Theory. 30(2011)173-200.

8. Krishnan J, Song H. The Effect of Auditing Standard No. 5 on Audit Fees[J]. Auditing A Journal of Practice \& Theory.30(2011)1-27. 